\title{
Role of Manufacturing Sector and Trade, Hotel, Restaurant Sector In East Java's Economy: Input-Output Analysis
}

\author{
Anggari Marya Kresnowati, Candra Fajri Ananda, Moh. Khusaini \\ Economics Science Department, Brawijaya University, Indonesia \\ Email: anggari.marya50@gmail.com
}

Received: April 24, 2016; Accepted: September 13, 2016; Published: November 3, 2016 Permalink/DOI: http://dx.doi.org/10.17977/um002v8i22016p168

\begin{abstract}
This study aimed to (1) analyze the relationship the manufacturing sector and the trade, hotel, and restaurant sector with other sectors in East Java, (2) to analyze the economic impact caused the two sectors based on the multiplier effect, (3) and analyze the economic impact caused by these two sectors if there additional investment funds. This study uses data analysis input-output 2010 East Java 19x19 aggregation sector.The results indicate that base metals subsector has the highest linkages to other sectors. Based on household income multiplier effect, trade subsector has the greatest multiplier. Employment multiplier in trade and industrial sectors are in medium rank. This indicates that the labor has been absorbed well in both sectors. The output multiplier effect, subsector non-metal goods, except petroleum and coal has the highest multiplier. The last, according to the analysis of investment injection simulations Input-Output East Java in 2010, subsector other processing industries has a best value added. Overall, the manufacturing sector has a better influence to East Java's economy than trade, hotel, and restaurant sector.
\end{abstract}

Keywords: sectoral linkages, multiplier, investment, input-output analysis, the manufacturing sector, trade hotel restaurant sector

JEL Classification: D57, 014

\section{INTRODUCTION}

As the analysis of the economic development develops, the relation among sectors obtains more concern. The economic development is not only seen from its growth, but also concern on its growth difference between production factor and source of growth. The Lewis analysis (Mahyudi, 2004), revealed that how vital the balanced development that gives more concern on foreseeable gain created by efficient interdependence among various sectors. According to Mahyudi (2004), if the economic development focuses only in one sector, many problems will appear. The economic development that does not have a balance among several sectors will cause instability and disturbance toward fluidity of economic activity.

The activity of production in economics cannot stand by itself. Each process of production requires input. Sector of production resulting input to another sector also requires input obtained from another sector in order to continue the process of production. Using products between goods and capital, the industry is getting more correlated each other, and even it creates interdependence relation (Boediono, 1992; Kuncoro, 2010) 
Manufacturer programs are separated into several stages to ease the implementation of manufacturing program. The implementation of manufacture programs is based on priority scale that has been set from the leading sector of economics for another sector. The leading sector is the sector that has the most multiplier effect, backward linkage, and forward linkage. The priority taken from the leading sector can encourage other manufacture sectors and improve the national manufacture in general and its notable area. Moreover, it also improves citizen wealth in accordance with the goal of the manufacturer.

The government of East Java Province as one of the major province whose 38 regencies/cities has duty and authority in the implementation of autonomy area program in accordance with law. Over the time, the area structure may not in static state eternally. The change of the area structure due to the difference of the growth capability among sectors. The existence of particular sector cannot be achieved without support from other sectors. The inter-industry relationship later can be recorded in one instrument statistic, that is Input-Output table (IO).

The change of the structure expected from the economic growth relates to the capital investment, either domestic or foreign capital. The East Java Province has big enough potential as the investment target if it is viewed from the data of the capital investment location trends. In accordance with the background stated above, the researcher would like to observe further related to two sectors that provide the biggest investment and the biggest PDRB for the East Java Province, the processing industry sector and trade, hotel, and restaurant sectors. The researcher would also like to observe the subsectors from both sectors above that are more superior and promising as the target sector of investment with big added value for the East Java Province via the input-output analysis. Besides, the researcher also would like to observe the correlation of both primary sectors above.

\section{LITERATURE REVIEW}

According to Daryanto \& Hafizrianda (2010), regions have the discretion to manage and solve the problems of development in the area. Business opportunities in the area are also open to further build regional competitiveness. Regional development planning is to combine all the interests, both from the government, public, or private. The sectoral approach or field are accommodated and aligned in a systematic and dynamic planning (Conyers \& Hills, 1994).

\section{Regional Planning}

Arsyad (2010); Todaro \& Smith (2006) suggests the following: Planning means choosing; Planning is a means of allocating resources; It is a tool to achieve goals, and; Planning oriented to the future. There is not decision-making that must be implemented immediately, and each has its own time period. Planning itself is a decision-making for better conditions in the future. The Importance of planning put forward by the following factors. The potential of the area is limited and cannot be updated; Technological development; Planning mistakes that have been implemented on the ground often cannot be changed and repaired.

\section{Theory Policy Making}

According to Dun (2003) in his book Introduction to Public Policy Analysis, policy action has two main objectives of the regulation and allocation. 


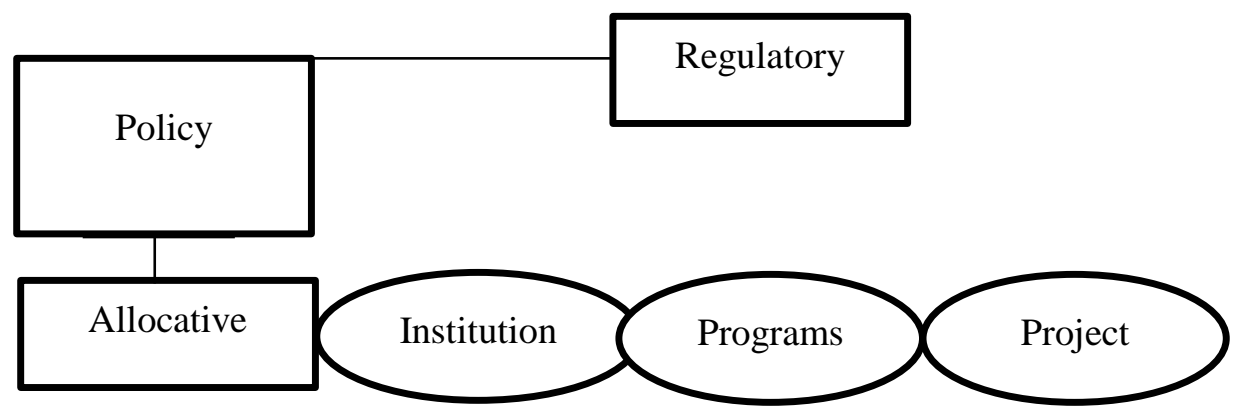

Figure 1. Regulatory actions and allocative and its implementation through agencies, programs, and projects

Input from these policies may include time resources, financial resources, human resources and material resources, which are used to produce the outputs or impacts. As an example of the input, the policy is budget, which contains a systematic count of the resources to be allocated for program activities.

\section{Input-Output Analysis}

According to Nazara (2005), input-output analysis into an analysis tool that is excellent in describing the linkages between sectors. Table I-0 is a matrix that describes the transaction of the economy within the region and within a certain time.

Input-Output Table is a data presentation system. Leontif (1985) describes that this analysis is a systematic analysis tool that calculates the relevant economic sectors are complex. (BPS East Java, 2010). Input-Output Analysis included in the three assumptions, namely:

1. Homogeneity assumption, namely that of a commodity or product is only produced singly by sector unit

2. Linearity assumption, namely that the production function is linear and homogenous

3. Adivity assumptions, the total effect of the implementation of the various sectors of production (BPS East Java, 2010)

Technically IO table can be used for:

As a basic estimate of the GDP of a region and as a basis for preparing the data is new base year calculation of the GDP. As the analysis of various policies in the macroeconomy in anticipation of changes in the provision (supply) and demand (demand) of various goods and services.

\section{Investment Theory}

Investment is one of the major driving force in the economic growth of a country (Pekarskiene \& Susniene, 2014). In relation to production, this investment can be used to add to, replace supplies the engine, so that later the production capacity can be increased. Investment in Indonesia, as set in the law governing capital investment is divided into two, namely foreign investment and domestic investment.

Investment plays an important role in the development process long-term economic growth. The process of economic development requires investment role as an advocate for economic development. This investment could be the replacement of plant machinery, manufacturing offices, and investments in 
infrastructure that will be very influential for the sustainability of economic development of a country and have had an impact as an increase in people's income.

Investments are able to create new jobs which in turn will reduce the unemployment rate. Todaro \& Smith (2006) also suggested that the investment part of the national income or national expenditure (national expenditure) which is specifically designed to produce capital goods or capital in a given period.

\section{METHOD}

This study is quantitative. The data employed in this study is the secondary data. The data that is required in this study is the East Java Input-Output Table (IO) based on the producer price in a year period of 2010. The data is obtained from the Central Statistic Institution (BPS) of the East Java Province. The data used in this study is limited only in 2010.

The researcher uses 19 sectors classification that is aggregation from the Input-Output table of the 110 sectors East Java Province. Those sectors above include trade, hotel, and restaurant sectors and the processing industry. The main consideration of the classification relies on the interest of the study, to see the effect of sectoral interaction or obtain the superior product. In addition, the researcher also would like to see the effect of the development of one exogen variable toward the change of the production output sector only, so that the total transaction based on the producer price is used. Apart from the data above, the researcher takes the data of the development of the East Java investment from Capital Investment Institution and Gross Regional Domestic Product according to the East Java constant price at the same range time.

The analysis used in this study is the quantitative approach. The method of the quantitative analysis used in this study uses the IO table analysis approach that is employed as the basic framework to map the investment area. In order to see the effect of the investment of several economic sectors in the East Java Province, the researcher uses two approaches:

1. The Input-Output data approach based.

2. The approach that uses simulation process toward the investment activity to the economic sector.

The input-output analysis used in this study is multiplier analysis, the multiplier analysis used is the output multiplier, income multiplier, and employment multiplier. From this analysis, it can be acknowledged the superior economics sectors projection in the East Java Province.

1) Calculating Matrix

Calculating Input coefficient

$$
a_{i j}=\frac{z_{i j}}{X_{j}}
$$

In which:

$\mathrm{a}_{\mathrm{ij}}=$ input coefficient sector $\mathrm{i}$ by sector to $\mathrm{j}$

$\mathrm{Z}_{\mathrm{ij}}=$ input usage sector to $\mathrm{i}$ by sector to $\mathrm{j}$ (within rupiah standard)

$\mathrm{X}_{\mathrm{j}}=$ input total sector to $\mathrm{j}$ (within rupiah standard); output total (Xi)

Within particular domestic transaction IO table based on producer price, an input coefficient matrix is a group of various input coefficient called matrix $\mathrm{A}^{\mathrm{d}}$.

2) Calculating $\left(\mathrm{I}-\mathrm{A}^{\mathrm{d}}\right)$ 
After obtaining matrix $\mathrm{A}^{\mathrm{d}}$, the next step is to gain multiplier matrix by decomposing matrix I (the identity matrix) with matrix $\mathrm{A}^{\mathrm{d}}$, by subtracting each paired cell.

$$
\left[\begin{array}{lll}
1 & 0 & 0 \\
0 & 1 & 0 \\
0 & 0 & 1
\end{array}\right]
$$

3) Calculating multiplier Matrix

$$
\text { Matrix of Identity (3x3) }
$$

Multiplier Matrix is defined as inverse matrix of $\left(I-A^{d}\right)$.

$$
B=\left(I-A^{d}\right)^{-1}
$$

In which:

$\mathrm{B}=$ multiplier matrix

$\mathrm{A}^{\mathrm{d}}=$ domestic input coefficient matrix (obtained from domestic transaction IO table based on production price)

The inverse matrix of $\left(\mathrm{I}-\mathrm{A}^{\mathrm{d}}\right)$ can be counted manually or via Microsoft Excel. In this way, the stage of counting the multiplier matrix using IO has been able to be implemented.

\begin{tabular}{|l|l|c|c|}
\hline & & \multicolumn{2}{|c|}{ Backwad Linkages } \\
\hline & & Low & High \\
\hline \multirow{2}{*}{$\begin{array}{l}\text { Forward } \\
\text { Linkages }\end{array}$} & Low & $\begin{array}{c}\text { The Potential } \\
\text { Superior } \\
\text { Sector } \\
\text { Group II }\end{array}$ & $\begin{array}{c}\text { The } \\
\text { Superior } \\
\text { Sector } \\
\text { Group I }\end{array}$ \\
\cline { 3 - 4 } & \multirow{2}{*}{ High } & $\begin{array}{c}\text { The Inferior } \\
\text { Sector }\end{array}$ & $\begin{array}{c}\text { The } \\
\text { Potential } \\
\text { Developed } \\
\text { Sector }\end{array}$ \\
\cline { 3 - 4 } & & Group IV & Group III \\
\cline { 3 - 4 } & & & \\
\hline
\end{tabular}

Figure 2. Economic sectors Based on The Dispersal Degree Index and The Sensitivity Degree Index

Source: East Java BPS 2010

The effect analysis is able to seize exogen variable effect in relative way. In order to acknowledge the change effect of exogen variable toward output, the simulation analysis can be used. In this way, injection scenario that is an investment toward variable will be used.

The subsector on industry sector and trade, hotel, and restaurant sector, the result from the calculation of input-output that is included on advanced, potential, and developed sector will be given injection simulation in the form of $10 \%$ investment fund to each sector. In this way, it will reveal which sector will give the biggest output return. These sectors having the biggest output return are able to be used as reference of investment target in East Java Province.

Investment within the last demand on Input-Output table is the combination between Gross Fixed Capital (PMTB) and the stock change occurred in economics. 
In order to see the effect of investment injection, $10 \%$ will be added to Gross Fixed Capital (PMTB) variable under the number 303 as the code and the stock change will have 304 as the code.

\section{RESULT AND DISCUSSION}

The Forward Linkage and The Backward Linkage of Processing Industry and Trade, Hotel, and Restaurant Sectors

The trade sector is a competitive enough sector with its big contribution to PDRB of the East Java Province. Within production sector, the relationship among sectors causing economics interaction is backward linkages relationship or upstream linkage and forward linkages or downstream linkages. The total index of backward linkages having greater score than one reveals that these sectors having strong capability to attract the output growth of its upstream sector. The total index of forward linkages having greater score more than one shows that these sectors having strong capability to support the production growth of another sector that use this sector input.

The sector that has index score of sensitivity degree (showing forward linkages) and the dispersal index energy (showing backward linkages) above 1,00 is the sector that is recommended to develop in order to support the growth of other sectors within the growth of local economies. These sectors are categorized into quadrant 1 . The following picture is the division of the dispersal energy quadrant and the sensitivity degree in the East Java Province.

\begin{tabular}{|c|c|c|c|}
\hline \multirow{4}{*}{ : } & $\begin{array}{l}1,6 \\
1,4\end{array}$ & $\begin{array}{l}\text { QUADRANT 2 } \\
\text { THE POTENTIAL } \\
\text { SUPERIOR SECTOR } \\
\text {-Chemical, petroleum } \\
\text { Rubber } \\
\text {-Trade }\end{array}$ & \multirow[t]{2}{*}{$\begin{array}{l}\text { QUADRANT } 1 \\
\text { THE SUPERIOR SECTOR } \\
\text {-Basic metal }\end{array}$} \\
\hline & 1,0 & & \\
\hline & 0,4 & $\begin{array}{l}\quad \text { QUADRANT } 4 \\
\text { THE INFERIOR SECTOR } \\
\text {-Textile, readymade } \\
\text { clothes, and leather } \\
\text {-Wood } \\
\text {-Goods made of metal, } \\
\text { machine } \\
\text {-Hotel }\end{array}$ & $\begin{array}{l}\text { QUADRANT } 3 \\
\text { THE POTENTIAL } \\
\text { DEVELOPPED SECTOR } \\
\text {-Food and beverage,tobacco } \\
\text {-The paper \& publication } \\
\text {-Another industrial } \\
\text {-Restaurant } \\
\text {-The non-metal excavated } \\
\text { goods non logam }\end{array}$ \\
\hline & 0,2 & 0,5 & 1,0 \\
\hline
\end{tabular}

Figure 3. The Dispersal Energy Index and The Subsector Sensitivity Degree Toward the Processing Industry Sector and The Trade, Hotel, and Restaurant Sectors In The East Java Province

Source: The Processed Data in 2016 
Table 1. The Superior Sector (Backward and Forward Linkages is more than 1)

\begin{tabular}{ccc} 
Subsector & The Dipersal Degree Index & The Sensitivity Degree Index \\
\hline Basic Metal & 1,147993582 & 1,015125767
\end{tabular}

Source: The Processed Data in 2016

The picture above, in general, describes the superior sector in East Java for instance farming sectors, the basic metal industry sector, and monetary sector. The basic metal is only the industry subsector that becomes the focus of the study. It is included in superior group under the dispersal energy index equal to 1,147993582 and the sensitivity degree index equal to 1,015125767 .

This phenomenon shows that the government of East Java Province surely focuses to develop the superior sector based on the result of the input-output calculation. If this basic metal sector is continually developed, it will attract and encourage the growth of other sectors. This subsector is the second highest subsector in East Java after another electric machine subsector. The most of industry population are dispersed in Sidoarjo, Gresik regency and Surabaya (Amir \& Nazara, 2005).

Table 2. The Potential Developed Sectors (Forward Linkages more than 1 dan Backward Linkages less than 1)

\begin{tabular}{lll}
\hline \multicolumn{1}{c}{ Subsectors } & \multicolumn{1}{c}{$\begin{array}{c}\text { The Dipersal Degree } \\
\text { Index }\end{array}$} & $\begin{array}{c}\text { The Sensitivity Degree } \\
\text { Index }\end{array}$ \\
$\begin{array}{l}\text { Chemical, petroleum } \\
\text { Rubber }\end{array}$ & 0,904130986 & 1,531079137 \\
Trade & 0,909042723 & 1,269443917
\end{tabular}

Source: The Processed Data in 2016

Based on the result of input-output calculation of East Java in 2010, there are two subsectors within the trade, hotel, and restaurant sectors and processing industry sector having sensitivity degree index more than one, while the dispersal energy index is below one. It means that these sectors do not maximally benefit the between input within economics sector. The production activity does not influence the development of the upstream sector very much or between demand. The input used in this sector that is obtained from another sector is small and probably is come from import.

There are some commodities at the chemical, petroleum, rubber, and plastic industry such as basic chemical, pesticide, fertilizer, soap; cleaning goods; and cosmetic, refinery goods, pharmacy, traditional medicine, rubber and goods made of rubber, and goods made of plastic. Meanwhile, at the trade sector, the commodity includes a big trade that does not sell car or motorcycle, and retail trade that does not sale car or motorcycle, and trade; reparation; and the car and motorcycle garage. 
Table 3. The Potential Superior Sectors (Backward Linkages more than 1 dan Forward Linkages less than 1)

\begin{tabular}{|c|c|c|}
\hline Subsectors & $\begin{array}{c}\text { The Dipersal Degree } \\
\text { Index }\end{array}$ & The Senstivity Degree Index \\
\hline $\begin{array}{l}\text { Food and beverage, } \\
\text { tobacco }\end{array}$ & 1,07277686 & 0,919260055 \\
\hline The paper \& publication & 1,000897767 & 0,921928815 \\
\hline Another industrial & 1,052258033 & 0,848020973 \\
\hline Restaurant & 1,036865516 & 0,814752177 \\
\hline $\begin{array}{l}\text { The non-metal excavated } \\
\text { goods non logam }\end{array}$ & 1,176528091 & 0,842822581 \\
\hline
\end{tabular}

Source: The Processed Data in 2016

At the table above, the dispersal energy index is above one while the sensitivity degree index is below one. This phenomenon reveals that sectors within this group are able to increase the productivity of other sectors with its raw material demand, nevertheless the capability to support the economics activity obtained from its output is still below average at all sectors. It reflects that subsector within this sector in East Java is the potential input provider to other sectors within one province. The majority of this group consist of subsectors that directly become the last consumption sector and they are not reprocessed to be input.

The last group sectors are the inferior sectors since these sectors are not able to support the economics with its raw material demand and they also are not able to support another economics activity of its output supply. The sectors within this group are dominated by product/commodity that is directly consumed by the last demand so that it does not become input for other sectors and the majority input of this sector comes from import outside of East Java and its raw material comes from outside region.

Table 4. The Inferior Sectors (Backward and Forwards Linkages less than 1)

\begin{tabular}{lcc}
\multicolumn{1}{c}{ Subsector } & The Dipersal Degree Index & $\begin{array}{c}\text { The Sensitivity Degree } \\
\text { Index }\end{array}$ \\
\hline $\begin{array}{l}\text { Textile, readymade } \\
\text { clothes, and leather }\end{array}$ & 0,893255885 & 0,8337 \\
\hline Wood & 0,979368074 & 0,98286 \\
\hline $\begin{array}{l}\text { Goods made of metal, } \\
\text { machine }\end{array}$ & 0,843100538 & 0,8909 \\
\hline Hotel & 0,939380519 & 0,8452 \\
\hline
\end{tabular}

Source: The Processed Data in 2016

\section{The Analysis of Multiplier Income}

The following table illustrates the number of multiplier income in East Java input-output number in 2010. The multiplier income is the number of total income that is created (including some of income that is expensed again in economics) from the addition of one last demand money unit in particular sector.

Table 5. The Income Multiplier based on Input-Output Analysis 2010

\begin{tabular}{ccc}
\hline Sectors & Subsectors & Multiplier Income \\
\hline Industry & Food and beverage, tobacco & 0,226707076 \\
\hline
\end{tabular}




\begin{tabular}{ccc}
\hline Sectors & Subsectors & Multiplier Income \\
\hline & Textile, readymade clothes, and \\
leather & 0,124734665 \\
& Woods & 0,163860194 \\
\cline { 2 - 3 } & The paper \& publication & 0,328098552 \\
\cline { 2 - 3 } & Chemical, petroleum rubber & 0,147254083 \\
\cline { 2 - 3 } & The non-metal excavated goods & 0,274324126 \\
\cline { 2 - 3 } Trade, Hotel, & Basic Metal & 0,301378055 \\
\cline { 2 - 3 } and Restaurant & Goods made of metal, machine & 0,085478375 \\
\cline { 2 - 3 } & Another Industrial & 0,142209992 \\
\cline { 2 - 3 } & Trade & 0,478935639 \\
\hline Source: The Procel & 0,455865794 \\
\hline
\end{tabular}

Source: The Processed Data in 2016

The sector that has the highest multiplier income is the trade, hotel, and restaurant sectors. The trade subsector gives 0,478935639 and the industry subsector of paper subsector, printing, publication have 0,328098552. Nevertheless, they are still below the hotel subsector that has multiplier income equals to 0,455865794 . The aforementioned numbers mean that each improvement of one last demand money unit in the subsector, the output of trade subsector will improve the total income equals to 0,478935639 . This condition is also applied to other subsectors.

The trade, hotel, and restaurant sectors are indeed more superior in terms of its contribution to PDRB of East Java. According to the coefficient of fee and salary inside the input-output number of East Java in 2010, it is obtained that the trade subsector has the highest coefficient among all economic sectors. Almost $44 \%$ of the output total that circulates is used to pay the labor's service in the form of fee and salary. The hotel allocates about $39 \%$ and the paper, printing, and publication industry allocates $25 \%$ from the output total to pay the fee. Hence, based on the result of the calculation above stating that this subsector is indeed the highest multiplier income.

The sectors that relatively have solid capital and solid technology tend to have a relatively small coefficient. It is based on the goods subsector of metal, machine, and tools having the smallest multiplier number. The value of the multiplier income is dimensionless so that it is mentioned in set of unit or money unit. (Nazara, 2005:48)

\section{The Employment Multiplier}

The employment multiplier is the total effect from the employment change on economics as a result of a change on the last demand at particular sector (Bekhet, 2011) The change of the last demand at particular sector will cause change at the employment demand. This employment multiplier is mentioned in the set of employment. In order to seize the change effect of the last demand for the employment change in all economics, it is required the initial employment or the initial number of workforce at each subsector investigated. Nonetheless, due to the lack of the available workforce data, it will only be presented the number of the 
employee who works only in one sector and there is no possibility of working in two or more sectors at the same time.

Table 6. The Employment Multiplier based on Input-Output Analysis 2010

\begin{tabular}{clc}
\hline No. & \multicolumn{1}{c}{ Sectors } & The Employment Multiplier \\
\hline 1. & Agriculture & 0,019936518 \\
\hline 2. & Mining & 0,002696478 \\
\hline 3. & Industry & 0,003471995 \\
\hline 4. & Electricity & 0,003378786 \\
\hline 5. & Construction & 0,00564765 \\
\hline 6. & Trading & 0,008525109 \\
\hline 7. & Transportation & 0,004443854 \\
\hline 8. & Finance & 0,010963993 \\
\hline 9. & Services & 0,011142349
\end{tabular}

Source: The Processed Data in 2016

The number of the multiplier employment is 0,003471995 . This number reveals that if there is an increase of the last demand equals to 1 milliard rupiahs in industry sector, it will give the additional about 3 new employment in economics. The trade sector is also the same, it will provide additional about 8 new employment if the last demand of the aforementioned sector is increased to 1 milliard.

The employment multiplier of trade sector and industry sector are at the middle to below ranking. The industry sector ranks $7^{\text {th }}$ and the trade sector at the $4^{\text {th }}$ ranking. This phenomenon does not always have a negative meaning. It reveals that the workforce absorbed by the industry sector has been big enough as the output resulted by the aforementioned sector. On the contrary, the farming sector that has high multiplier employment is caused by the lack of workforce absorbed while the output obtained is very big, even though in East Java case the absorption of the farming sector has the highest score in terms of workforce.

The trade sector is still better in terms of multiplying the employment, in this case, it means that if the government would like to enlarge the employment, this sector should be given more concern, or sector with high multiplier employment becomes priority.

\section{The Analysis of the Output Multiplier}

In composing the analysis of the output multiplier at the general input-output table, it is obtained the result that the highest value of output multiplier comes from industry sector the non-metal excavated goods subsector, except petroleum and coal equals to 1,511282466. The second, third, and fourth-ranking respectively later are still in the industry sector, for instance, basic metal subsector, food and beverage sector, tobacco, and another industry subsector. The trade sector restaurant subsector places $5^{\text {th }}$ ranking with its output multiplier equals to 1,331882074 .

Table 7. The Output Multiplier based on Input-Output Analysis 2010

\begin{tabular}{cll}
\hline Sectors & \multicolumn{1}{c}{ Subsectors } & \multicolumn{1}{c}{ Total } \\
\hline \multirow{2}{*}{ Industry } & Food and beverage,tobacco & 1,378011175 \\
\cline { 2 - 3 } & Textile, readymade clothes, and leather & 1,147411581 \\
\cline { 2 - 3 } & Woods & 1,25802504 \\
\hline
\end{tabular}




\begin{tabular}{cll}
\hline \multicolumn{1}{c}{ Sectors } & \multicolumn{1}{c}{ Subsectors } & \multicolumn{1}{c}{ Total } \\
\hline & The paper \& publication & 1,285680518 \\
\cline { 2 - 3 } & Chemical, petroleum, rubber & 1,161380944 \\
\cline { 2 - 3 } & The non-metal excavated goods & 1,511282466 \\
\cline { 2 - 3 } & Basic Metal & 1,47462911 \\
\cline { 2 - 3 } & Goods made of metal, machine & 1,082985668 \\
\cline { 2 - 3 } Trade, Hotel, & Another Industrial & 1,351654182 \\
\cline { 2 - 3 } and Restaurant & Trade & 1,167690205 \\
\cline { 2 - 3 } & Rotel & 1,206659933 \\
\hline
\end{tabular}

Source: The Processed Data in 2016

The numbers of this output multiplier mean that if there is change or addition of one rupiah last demand at the aforementioned sector, it will add the total output in economics equals to the value of its output multiplier. If the goal that wants to be achieved is to maximize the effect toward the output of production sector in economics, so the addition of the last demand should be allocated at the sector with high output multiplier value. Although in this case, it ensures the maximal output addition effect, it should not be considered to take any decision. Several another indicator must be concerned by the decision maker in determining the decision since the input-output analysis tool has some weaknesses.

If the analysis result of output multiplier is compared with the income multiplier, the result will not be in the superior sector. A sector that has a high multiplier in one sector does not always become superior tool in another multiplier sector. It means that even though a sector has the small potency to produce output due to the increase of its demand, yet it is able to produce high-income potency, this condition is caused by this sector use more input coming from household or in other words this sector absorbs more the household workforce.

\section{The Comparison of the Effect of Economy that Rises through the Analysis of Investment Fund Simulation at the Processing Industry and Trade, Hotel, and Restaurant Sectors}

Investment in the last demand at the input-output table is the combination between Gross Fixed Capital (PMTB) and the stock change occurred in economics. The investment structure occurred at the industry sector is generally viewed higher than trade, hotel, and restaurant sectors. The PMTB and the stock change do not happen at the economic sectors in overall.

The highest PMTB that occur at trade, hotel, and restaurant sectors is at trade subsector equals to 26929137,65 million rupiahs, followed by another processing industry, and wood industry. The highest structure of the stock change happens at another processing industry equals to 4162658,69 million rupiahs, followed by food, beverage, and tobacco subsectors and chemical, petroleum, rubber, and plastic subsector industry.

The followings are the subsectors within the trade, hotel, and restaurant sectors and processing industry if it is given investment simulation according to the result of input-output analysis of East Java in 2010. This analysis is started with $10 \%$ addition at one of the subsectors and another subsector that is considered constant. This simulation is implemented toward 12 subsectors at the two sectors 
investigated. The following is the result of the $10 \%$ investment simulation analysis along with the output total of economics.

The subsector that gives the highest output if it is analyzed using investment injection simulation based on the East Java input-output in 2010 is another processing industry subsector. After that, the trade sector ranks second. The industry sectors are more dominant at the top rank sector with the greater output result. According to the input-output analysis of investment simulation, the industry sector is indeed more profitable to the East Java economics than the trade, hotel, and restaurant sectors if the investment is given.

Table 8. Total Output After Invest Simulation 10\%

\begin{tabular}{llll}
\hline \multicolumn{1}{c}{ Sectors } & $\begin{array}{c}\text { Total Before } \\
\text { Injection 10\% }\end{array}$ & $\begin{array}{c}\text { Total After } \\
\text { Injection } \\
\mathbf{1 0 \%}\end{array}$ & Deviation \\
\hline Another Industrial & 1327572314,81 & 1330333787 & 2761472,4800 \\
\hline Trade & 1327572314,81 & 1330265229 & 2692913,7650 \\
\hline Woods & 1327572314,81 & 1328111083 & 538768,2920 \\
\hline Goods made of metal, machine & 1327572314,81 & 1327954375 & 382060,0560 \\
\hline Food and beverage, tobacco & 1327572314,81 & 1327937064 & 364749,5565 \\
\hline Chemical, petroleum, Rubber & 1327572314,81 & 1327844033 & 271718,2550 \\
\hline The paper \& publication & 1327572314,81 & 1327828472 & 256156,7550 \\
\hline $\begin{array}{l}\text { Textile, readymade clothes, and } \\
\text { leather }\end{array}$ & 1327572314,81 & 1327788230 & 215915,1453 \\
\hline Basic metal & 1327572314,81 & 1327722739 & 150424,4450 \\
\hline The non-metal excavated goods & 1327572314,81 & 1327619647 & 47332,4210 \\
\hline Hotel & 1327572314,81 & 1327572315 & 0,1900 \\
\hline Restaurant & 1327572314,81 & 1327572315 & 0,1900
\end{tabular}

Source: The Processed Data in 2016

\section{CONCLUSION}

The backward linkages level of the processing industry having the highest dispersal energy index is the non-metal excavated goods industry subsector, except petroleum and coal, then followed by the basic metal industry subsector. Meanwhile, to the trade, hotel, and restaurant sectors only the restaurant subsector that has dispersal energy index above one. It shows that the processing industry has better capability than the trade, hotel, and restaurant sectors in attracting the output growth of its upstream sector. The highest score of the sensitivity degree index at the processing industry sector is the chemical, petroleum, rubber, and plastic industry subsector. While the highest score of the sensitivity degree index at among trade, hotel, and restaurant sectors is the trade subsector. It means that both of aforementioned subsectors have strong capability to support the output growth of its downstream sector or other sectors using this sector. Moreover, for the forward linkages, the processing industry sector is also more superior than the trade, hotel, and restaurant sectors.

The basic metal subsector is the subsector that is able to attract the growth of the upstream sector and to support the growth of its downstream sector. This subsector also has the greater output multiplier along with a high number of its linkage. This sector is very good to be increased its capacity as it is able to attract 
and support the growth of all economics sectors in East Java. The result of the analysis of income multiplier shows that the trade subsector has the highest score, then followed by the hotel subsector, and after that the paper, printing, and publication industry subsector. It reveals that these sectors in East Java Province are able to produce high-income potency.

The number of the employment multiplier to the trade sector and the industry sector is at the middle to the bottom ranking. This phenomenon does not always have a negative meaning. It reveals that the workforce absorbed by the industry sector has been big enough as the output resulted by the aforementioned sector. The number of the output multiplier as the last multiplier gains the highest output multiplier score that is found at the industry sector the non-metal excavated goods subsector, except the petroleum and coal. The trade sector restaurant subsector is at the fifth ranking. It reveals that the trade, hotel, and restaurant sectors are further left behind if it is compared with processing industry sector in producing the total output for economics.

Developing the economy sectors should be implemented at the superior sectors. The superior sector within the input-output means that it has great forward and backward linkages. The basic metal industry is the good sector to be developed in East Java. The industry of the non-metal excavated goods, except the petroleum and coal is also potential sector to be superior with the highest backward linkages. The chemical, petroleum, rubber, and coal, and trade also good to stimulate the output growth of the downstream sector.

The policy that can be taken if the local government would like to increase the income is by increasing the improvement of the last demand at the paper, printing, and publication, rubber, and plastic, and restaurant industry subsector. Within the employment multiplier, the processing industry sector and the hotel, restaurant sector is still left behind among other sectors. This phenomenon does not always have a negative meaning. It reveals that the workforce absorbed by the industry sector has been big enough as the output resulted by the aforementioned sector. Besides increasing the last demand, the government needs also to maintain the purchasing power of society by holding up the inflation rate at the safe limit and provide the available employment.

The government needs to guide the investment to the processing industry as its added value is the highest among all. Based on the investment simulation analysis, the processing industry is indeed promising sector in East Java in terms of its return, but the trade subsector must also be concerned and needed to allocate more fund to the trade, hotel, and restaurant sector so that the PDRB contribution can be maintained or improved. The climate of investment in East Java has been good enough also need to be maintained.

\section{REFERENCES}

Amir \& Nazara. (2005). Analisis Perubahan Struktur Ekonomi (Economic Landscape) dan Kebijakan Strategi Pembangunan Jawa Timur Tahun 1994 dan 2000: Analisis Input output. Jurnal Ekonomi dan Pembangunan Indonesia, 5(2), 37-55.

Arsyad, L. (2010). Ekonomi Daerah. Yogyakarta: BPFE-Yogyakarta.

Badan Koordinasi Penanaman Modal. (2016). Realisasi Penanaman Modal PMDN-PMA.www.bkpm.go.id. Maret 2016. 
Badan Koordinasi Penanaman Modal. Undang-undang Nomor 25 Tahun 2007 tentang Penanaman Modal. 2007, (Online), http:// www.jdih.kemenkeu.go.id/fulltext/2007/25tahun2007.HTM. accessed 03 April 2016.

Badan Pusat Statistik Provinsi Jawa Timur. (2010). Tabel Input Output tahun 2010 Provinsi Jawa Timur.Surabaya: BPS Propinsi Jawa Timur.

Bekhet, H.A. (2011). Output, Income and Employment Multipliers in Malaysian Economy: Input-Output Approach. International Business Research, 4(1), 208-223.

Boediono. (1992). Ekonomi Makro, BPFE Yogyakarta.

Conyers, D., \& Hills, P. (1994). An Introduction to Development Planning in the Third World, John Wiley \& Sons.

Daryanto, A., \& Hafrizianda, Y. (2010). Analisis Input-Output Dan Social Accounting Matrix Untuk Ekonomi Pembangunan Ekonomi Daerah. Bogor: PT penerbit IPB Press.

Dun, W. N. (2003). Pengantar Analisis Kebujakan Publik. Yogyakarta: Gadjah Mada University Press.

Kementerian Perindustrian Indonesia. (2016). Direktori Perusahaan Industri, (Online), (http://www.kemenperin.go.id/direktori-perusahaan), accessed 16 Agustus 2016

Kuncoro, M. (2010). Ekonomi Pembangunan. Jakarta: Erlangga.

Leontief, W. (1985). What It Takes to Preserve Social Equity. New York Times.

Mahyudi, A. (2004). Ekonomi Pembangunan dan Analisis Data Empiris. Bogor: Penerbit Ghalia Indonesia.

Nazara, S. (2005). Analisis Input-Output.Jakarta: Lembaga Penerbit FE UI.

Pekarskiene, I., \& Susniene, R. (2014). The Assesment of the Manifestation of Economic Globalization: The International Trade Factor. Procedia-Social Behavioral Sciences, 156, 392-397.

Tarigan, R. (2005). Ekonomi Regional: Teori dan Aplikasi. Jakarta: PT Bumi Aksara

Todaro, M. P., \& Smith, S. C. (2006). Pembangunan Ekonomi. Jakarta: Erlangga.

Undang-Undang Nomor 23 Tahun 2014 tentang Pemerintahan Daerah. 2005. Surabaya: Serba Jaya.

Undang-Undang Nomor 25 Tahun 2007 tentang Penanaman Modal. 2016. (www.bi.go.id). accessed 06 September 2016.

Undang-Undang Nomor 32 Tahun 2004 tentang Pemerintah Daerah. 2005. Surabaya: Serba Jaya.

Undang-Undang Nomor 33 Tahun 2004 tentang Perimbangan Keuangan Antara Pemerintah Pusat dan Pemerintah Daerah. 2005. Surabaya: Serba Jaya. 